\title{
Non-Isothermal Reduction Kinetics of Iron Ore Fines with Carbon-Bearing Materials
}

\author{
Abourehab Hammam ${ }^{1,2}$, Yi Cao ${ }^{1}$, Abdel-Hady A. El-Geassy ${ }^{2}$, Mohamed H. El-Sadek ${ }^{2}$, Ying Li ${ }^{1}$ (D) Han Wei ${ }^{1}$, \\ Mamdouh Omran 1,2,3,*(D) and Yaowei Yu ${ }^{1, *}$ \\ 1 State Key Laboratory of Advanced Special Steel, Shanghai Key Laboratory of Advanced Ferro Metallurgy, \\ School of Materials Science and Engineering, Shanghai University, Shanghai 200444, China; \\ aborehabelmenshawy@cmrdi.sci.eg (A.H.); cyQAQQQQ@shu.edu.cn (Y.C.); yingli@shu.edu.cn (Y.L.); \\ weihan@shu.edu.cn (H.W.) \\ 2 Central Metallurgical Research and Development Institute (CMRDI), Cairo 11421, Egypt; \\ elgeassy@cmrdi.sci.eg (A.-H.A.E.-G.); mhussien@cmrdi.sci.eg (M.H.E.-S.) \\ 3 Process Metallurgy Research Group, Faculty of Technology, University of Oulu, FI-90014 Oulu, Finland \\ * Correspondence: mamdouh.omran@oulu.fi (M.O.); yaoweiyu@shu.edu.cn (Y.Y.); \\ Tel.: +358-449183230 (M.O.); +86-2166136535 (Y.Y.)
}

check for updates

Citation: Hammam, A.; Cao, Y.; El-Geassy, A.-H.A.; El-Sadek, M.H.; Li, Y.; Wei, H.; Omran, M.; Yu, Y. Non-Isothermal Reduction Kinetics of Iron Ore Fines with Carbon-Bearing Materials. Metals 2021, 11, 1137. https://doi.org/10.3390/met11071137

Academic Editor: Pasquale Cavaliere

Received: 14 June 2021

Accepted: 15 July 2021

Published: 19 July 2021

Publisher's Note: MDPI stays neutral with regard to jurisdictional claims in published maps and institutional affiliations.

Copyright: (c) 2021 by the authors. Licensee MDPI, Basel, Switzerland. This article is an open access article distributed under the terms and conditions of the Creative Commons Attribution (CC BY) license (https:// creativecommons.org/licenses/by/ $4.0 /)$.

\begin{abstract}
This study investigates the non-isothermal reduction of iron ore fines with two different carbon-bearing materials using the thermogravimetric technique. The iron ore fines/carbon composites were heated from room temperature up to $1100{ }^{\circ} \mathrm{C}$ with different heating rates $(5,10,15$, and $20^{\circ} \mathrm{C} / \mathrm{min}$ ) under an argon atmosphere. The effect of heating rates and carbon sources on the reduction rate was intensively investigated. Reflected light and scanning electron microscopes were used to examine the morphological structure of the reduced composite. The results showed that the heating rates affected the reduction extent and the reduction rate. Under the same heating rate, the rates of reduction were relatively higher by using charcoal than coal. The reduction behavior of iron ore-coal was proceeded step wisely as follows: $\mathrm{Fe}_{2} \mathrm{O}_{3} \rightarrow \mathrm{Fe}_{3} \mathrm{O}_{4} \rightarrow \mathrm{FeO} \rightarrow$ Fe. The reduction of iron ore/charcoal was proceeded from $\mathrm{Fe}_{2} \mathrm{O}_{3}$ to $\mathrm{FeO}$ and finally from $\mathrm{FeO}$ to metallic iron. The reduction kinetics was deduced by applying two different methods (model-free and model-fitting). The calculated activation energies of $\mathrm{Fe}_{2} \mathrm{O}_{3} /$ charcoal and of $\mathrm{Fe}_{2} \mathrm{O}_{3} / \mathrm{coal}$ are 40.50-190.12 kJ/mol and $55.02-220.12 \mathrm{~kJ} / \mathrm{mol}$, respectively. These indicated that the reduction is controlled by gas diffusion at the initial stages and by nucleation reaction at the final stages.
\end{abstract}

Keywords: non-isothermal reduction; self-reducing composites; gasification; kinetics; iron ore fine; coal; charcoal

\section{Introduction}

The steel industry is considered an important sector owing to its significant impact on global growth and the economy. Recently, the manufacture of crude steel has risen dramatically [1]. The steel demand is anticipated to reach 1.5 times more than the present levels by 2050 to meet the demands of an increasing population [2]. Approximately 70\% of crude steel depends on fossil fuel, such as coke [3]. The amount of $\mathrm{CO}_{2}$ emitted by steelmaking factories was around 2.3 billion tons in 2007, while it is predicted to reach about 3.0 billion tons by 2050 [4]. Currently, the key challenges for the steelmaking industry are environmental pollution and greenhouse gas emission. Therefore, the growth of the steel industry requires developing new procedures that are economically viable and environmentally friendly [5].

Nowadays, the disposal of wastes such as slags, dusts, mill-scales, sludges and fines produced at various stages of iron and steel production is one of the key challenges of the global steel industry. The use of these wastes is a vital solution for resource conservation and pollution reduction. Furthermore, substituting by-products for natural resources can 
save energy and improve energy efficiency in manufacturing processes. This involves reducing natural resource exploitation and pollution reductions, as well as the use of alternative raw materials that have lower environmental impacts [6-9].

Up until now, a blast furnace is a principal method of hot metal production. It is reasonable to handle almost all-natural iron ores, and the molten pig iron produced can be used directly for steelmaking. However, certain limitations are inherent in the blast furnace process, such as depending on the expensive metallurgical coke and requiring supporting facilities such as raw materials agglomeration, coal carbonization and an offgas cleaning system [10-12]. Recently, significant attention has been paid to develop new iron-making technologies for achieving the best performance in decreasing energy consumption and carbon dioxide emission. All the alternative iron-making processes aim at eliminating or reducing the energy supply by metallurgical coke and consequently reduce $\mathrm{CO}_{2}$ emissions [13]. Coal represents the biggest available energy resource in the world. Additionally, the variations in the prices of crude oil and fossil coke exposed that coal will remain less expensive, and its price is still more stable compared with other energy resources. In the direct reduction process (DRI), there is a good resilience among different types of fossil fuel such as lower-grade non-coking coal, charcoal and biomass as well as gaseous hydrogen-rich reductants to reduce the iron ores to sponge iron. It is thus essential to have an insight into the reduction characteristics and fundamental mechanisms for the different fossil fuels $[14,15]$.

The effect of reduction parameters, for example, reduction temperature, retention time, the molar ratio $(\mathrm{C} / \mathrm{O})$, iron ore and carbon particle sizes and different additives, on the reduction process were adequately examined by several researchers [16-23]. In general, most of these studies focused on raw materials and the products after the reduction, but only a few works predict the kinetics parameters of iron ore reduced by carbon, which is the significant factor in the reaction mechanism. Huang and Lu [24] established an amended model for the reaction kinetic which includes both the Boudouard reaction and variance in surface area to describe the reduction mechanism of iron oxide/carbon mixture. Dutta et al. [25] and Sun [26] found that the de-volatilization of coal affected the reduction behavior of ore-coal composite. Sun et al. [27] determined that the mechanism of reduction of oolitic iron ore with coal depends on the experimental conditions, and the controls of the reduction were also elucidated at various stages. Sun et al. [28] proposed a mathematical model which includes 19 separate equations to predict the non-isothermal reduction kinetics of ore/coal composites.

In the framework of developing new raw materials and methods for the steelmaking industry, it is necessary to study the kinetics of reaction for each material and its impact on the reduction process. The present study focuses on the reduction of iron ore finecoal/charcoal mixtures, which are non-isothermally experimented at different heating rates under argon atmosphere using thermogravimetric (TG) technique and additionally, compares the kinetic reduction results of charcoal with those of coal.

\section{Theoretical Kinetic Analysis}

In the kinetic analysis of reduction reactions, the reduction extent or conversion fraction $(\alpha)$ can be expressed as follows:

$$
\alpha=\frac{W_{i}-W_{T}}{W_{i}-W_{\infty}}
$$

where $W_{\mathrm{i}}$ represents the initial weight of the sample, $W_{T}$ represents the actual weight of the sample at a given temperature and $W_{\infty}$ is the maximum theoretical weight loss. The overall reaction rate is described as follows [29]:

$$
\frac{\mathrm{d} \alpha}{\mathrm{d} t}=A \exp \left(\frac{-E_{a}}{R T}\right) f(\alpha)
$$


where $A$ is the pre-exponential factor, $E_{a}$ is the apparent activation energy, $f(\alpha)$ is the differential conversion function, $R$ is the gas constant and $T$ is the absolute temperature. The sample is heated at a constant rate $(\beta)$ with non-isothermal conditions. In Equation (2), the explicit temporal is removed by using the trivial transformation.

$$
\frac{\mathrm{d} \alpha}{\mathrm{d} T}=\frac{\mathrm{d} \alpha}{\mathrm{d} t} \times \frac{\mathrm{d} t}{\mathrm{~d} T}=\frac{A}{\beta} \exp \left(\frac{-E_{a}}{R T}\right) f(\alpha)
$$

Integration Equation (3), it will become:

$$
g(a)=\int_{0}^{a} \frac{\mathrm{d}(a)}{f(a)}=\frac{A}{\beta} \int_{0}^{T} \exp \left(\frac{-E_{a}}{R T}\right) d T
$$

There are numerous approaches for evaluating the kinetic parameters under nonisothermal conditions $[29,30]$. This research applies two different mathematical approaches to analyze the kinetic reaction parameters: those two methods are model-free (isoconversional) and model-fitting [31,32].

Isoconversional way estimates kinetic parameters without any model assumptions [31-33]. This method is based on the assumption of variation of the reaction rate with the temperature at a given conversion degree [34]. A representative example of this method is the Kissinger-Akahira-Sunose (KAS Equation (5)) approach, which has been commonly used to deduce the kinetic parameters.

$$
\ln \frac{\beta}{T^{2}}=\ln \left(\frac{A E_{a}}{g(\alpha) R}\right)-\frac{E_{a}}{R T}
$$

To determine the possible reaction mechanism, the model-fitting Coats and Redfern (CR) method was applied. The best statistical fit was employed to describe the reaction kinetics. CR method providing one of the most widespread model-fitting approaches [35].

$$
\ln \frac{g(\alpha)}{T^{2}}=\ln \left(\frac{A R}{\beta E_{a}}\left[1-\left(\frac{2 R T_{\exp }}{E_{a}}\right)\right]\right)-\frac{E_{a}}{R T}
$$

\section{Materials and Experimental Technique}

\subsection{Raw Materials}

\subsubsection{Iron Ore Fines}

Iron ore fines used in the present study were produced during the transmission and handling of the pellets in the DR plants. The mean particle size of this sample was $100 \mu \mathrm{m}$. The complete chemical analysis of the sample was carried out by X-ray fluorescence technique (XRF Advanced Axios, Almelo, Netherlands). The results are given in Table 1. $\mathrm{Fe}_{2} \mathrm{O}_{3}$ was the major component in the sample (96 wt \%).

Table 1. Complete chemical analysis of iron ore fine sample (wt \%).

\begin{tabular}{cccc}
\hline Component & Assay (\%) & Component & Assay (\%) \\
\hline $\mathrm{Fe}_{2} \mathrm{O}_{3}$ & 96.18 & $\mathrm{~K}_{2} \mathrm{O}$ & 0.024 \\
$\mathrm{SiO}_{2}$ & 1.62 & $\mathrm{P}_{2} \mathrm{O}_{5}$ & 0.039 \\
$\mathrm{CaO}$ & 0.977 & $\mathrm{MnO}$ & 0.093 \\
$\mathrm{Al}_{2} \mathrm{O}_{3}$ & 0.655 & $\mathrm{~V}_{2} \mathrm{O}_{5}$ & 0.051 \\
$\mathrm{MgO}$ & 0.099 & $\mathrm{Cr}_{2} \mathrm{O}_{3}$ & 0.024 \\
$\mathrm{TiO}_{2}$ & 0.082 & $\mathrm{SrO}$ & 0.013 \\
$\mathrm{SO}_{3}$ & 0.054 & $\mathrm{NiO}$ & 0.018 \\
$\mathrm{Na}_{2} \mathrm{O}$ & 0.011 & $\mathrm{Cl}$ & 0.019 \\
\hline
\end{tabular}

The different phases present in the sample were identified by X-ray diffraction (XRD) PW 1730 (Bruker axs D8, Karlsruhe, Germany) equipped with Cu radiation $(\lambda=1.5 \AA$, at 
$40 \mathrm{kV}$ and $30 \mathrm{~mA}$ ). The XRD chart is shown in Figure 1, where hematite is the main phase detected in the sample.

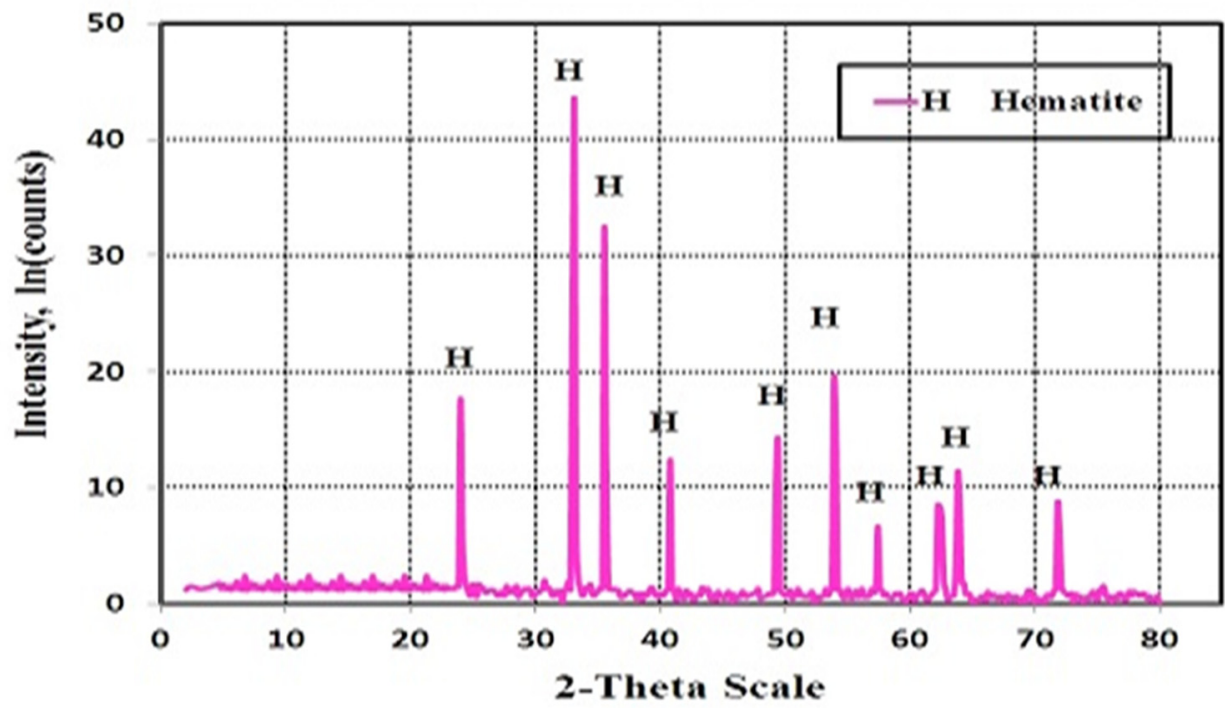

Figure 1. X-ray diffraction analysis of iron ore fines sample.

Scanning electron microscope (SEM) JEOL, JSM-5410 at10Kv (JEOL 1td, Akishima, Tokyo, Japan) and reflected light microscope (RLM) Zeiss Axio Scope A1 (Zeiss, Oberkochen, Germany) were used to examine the morphology and microstructures of the sample. The SEM and RLM images are given in Figure 2a,b, respectively. Figure 2a illustrates that the internal structure contains pieces of various sizes, which come from the disintegration and abrasion of original pellets during transportation. The RLM photomicrograph indicates that the structure is composed of a relatively dense matrix, as given in Figure $2 b$.
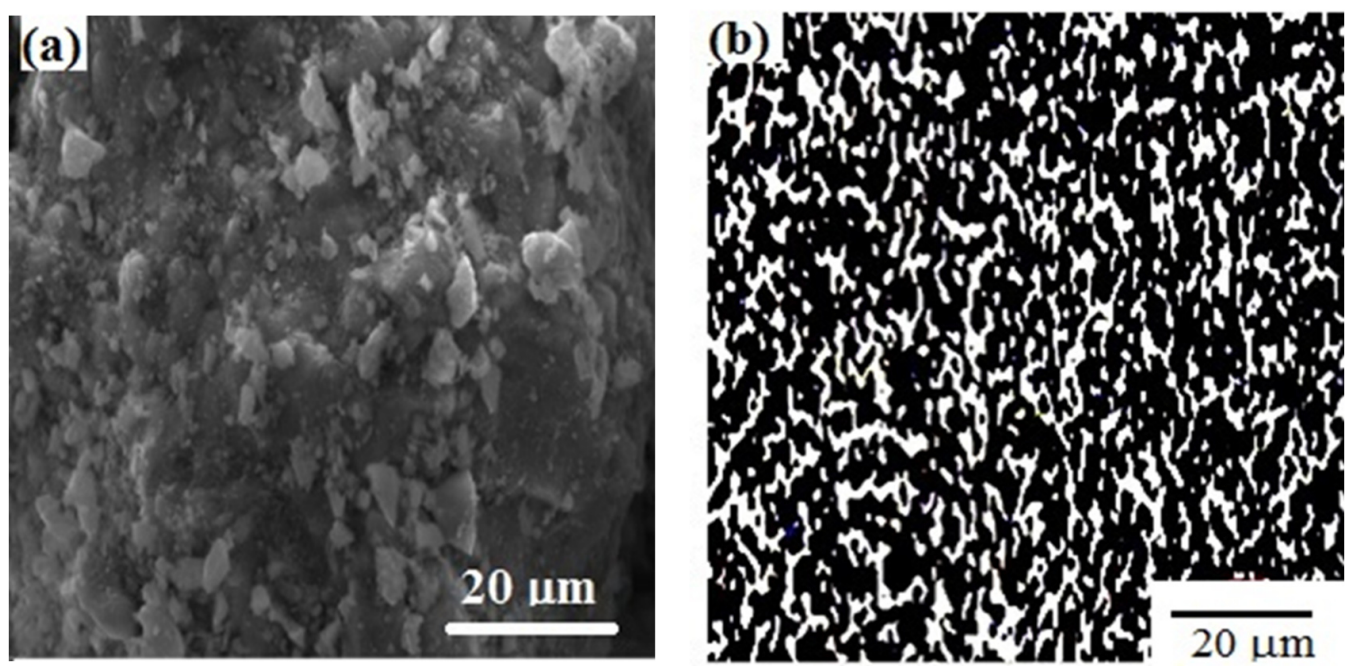

Figure 2. Photomicrographs of iron ore fines sample (a) SEM $(5000 \times)($ b) RLM $(500 \times)$.

\subsubsection{Carbon-Bearing Materials}

Coal and charcoal are the two types of non-coking materials that are used as reducing agents. Their proximate analysis is listed in Table 2. The charcoal has a higher fixed carbon (C) and lowers ash content than coal. The specific surface area of charcoal and coal is 625.5 and $316.4 \mathrm{~cm}^{2} / \mathrm{g}$, respectively. 
Table 2. Proximate analysis of coal and charcoal (wt \%).

\begin{tabular}{ccccc}
\hline Coal Type & Moisture & Ash & Volatiles & Fixed Carbon \\
\hline Coal & 4.5 & 4 & 33.5 & 58 \\
Charcoal & 9 & 3 & 14 & 74 \\
\hline
\end{tabular}

The SEM images of charcoal and coal are shown in Figure 3a,b, respectively. Charcoal (Figure 3a) is characterized by longitudinal and fine grains, while coal (Figure $3 b$ ) is composed of block and fine grains.
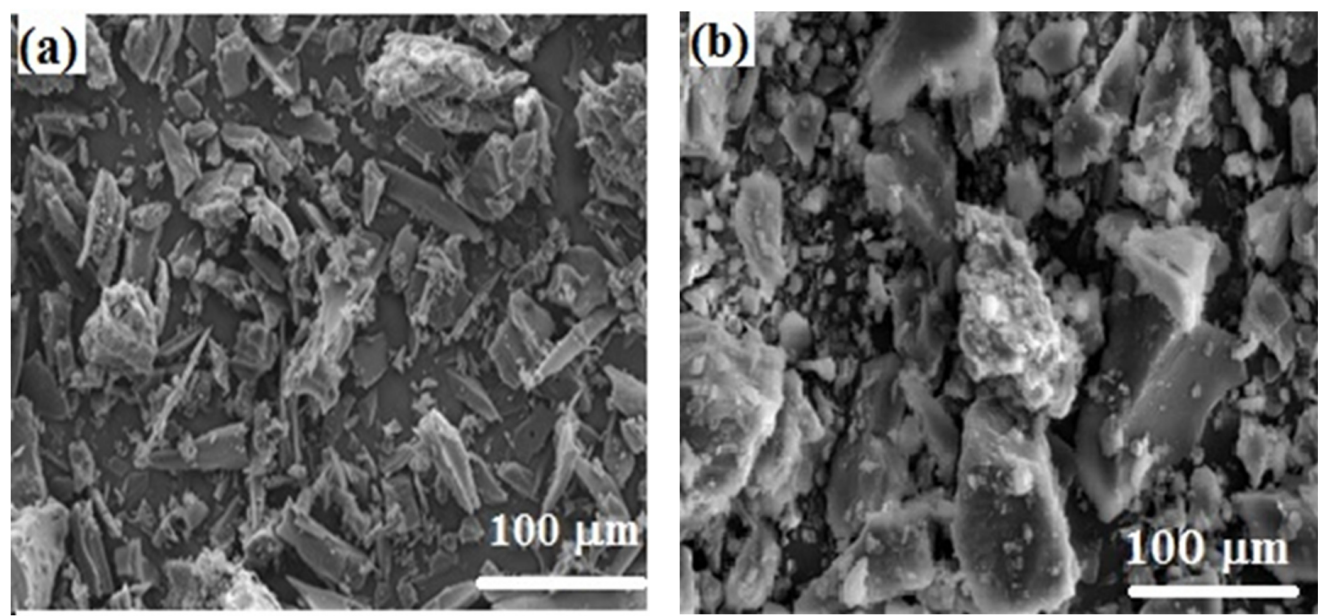

Figure 3. SEM images of non-coking coal samples: (a) charcoal and (b) coal.

Charcoal and coal samples were heated up to $1100^{\circ} \mathrm{C}$ in the $\mathrm{CO}_{2}$ atmosphere to follow up its gasification rates using the TG technique. The TG and derivative thermogravimetric (DTG) curves for coal and charcoal are shown in Figure 4. It is clear that both carbonbearing materials have exhibited three weight loss steps, as given in Table 3. The liberation of coal volatiles was started at about $300{ }^{\circ} \mathrm{C}$ and ended at $550{ }^{\circ} \mathrm{C}$ with a marked peak in the DTG curve, which ensures the complete removal of all volatiles. While in the case of charcoal, the de-volatilization started at $550{ }^{\circ} \mathrm{C}$ and stopped at $700{ }^{\circ} \mathrm{C}$ with a small peak in DTG. The gasification of coal and charcoal nearly starts at the same temperature, $800^{\circ} \mathrm{C}$. Furthermore, charcoal gives a stronger peak in DTG than coal. This behavior could be attributed to the higher surface area and fixed carbon.

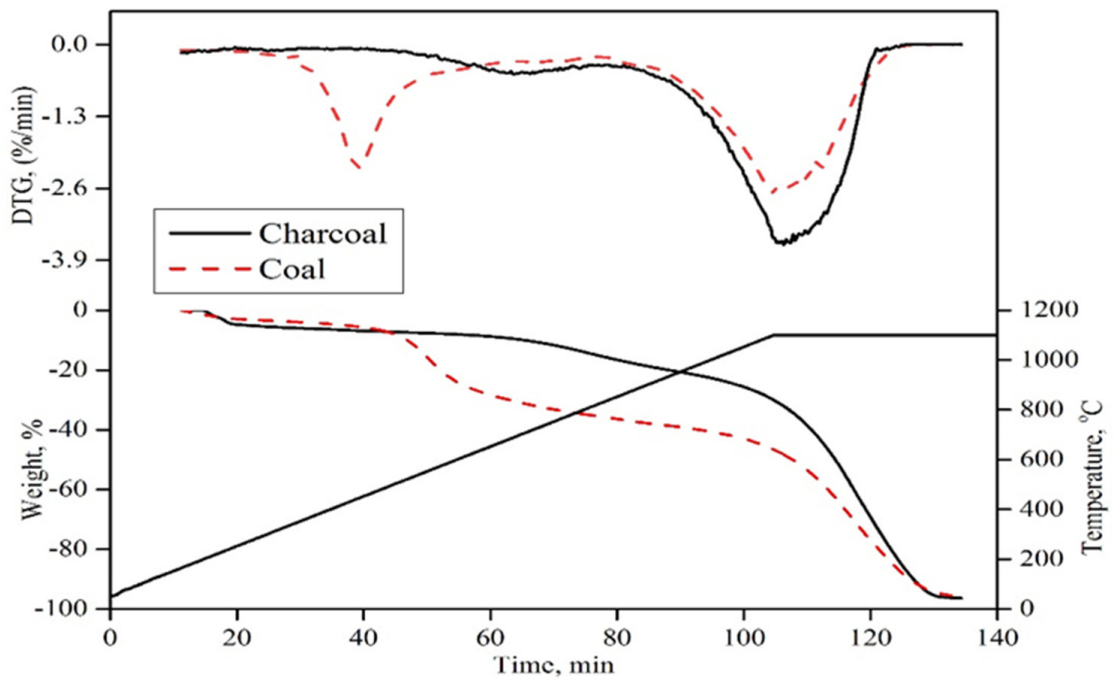

Figure 4. Gasification of charcoal and coal in $\mathrm{CO}_{2}$ atmosphere up to $1100{ }^{\circ} \mathrm{C}$. 
Table 3. Behaviors of charcoal and coal in $\mathrm{CO}_{2}$ atmosphere heating up to $1100{ }^{\circ} \mathrm{C}$ from the room temperature.

\begin{tabular}{cccc}
\hline Materials & $\begin{array}{r}\text { De-Hydration } \\
\mathbf{8 0 - 1 2 0}{ }^{\circ} \mathbf{C}\end{array}$ & $\begin{array}{r}\text { De-Volatilization } \\
\mathbf{4 3 0 - 5 2 0}{ }^{\circ} \mathbf{C}\end{array}$ & $\begin{array}{c}\text { Gasification } \\
\mathbf{7 0 0}{ }^{\circ} \mathbf{C}\end{array}$ \\
\hline Coal & $5 \%$ & $35 \%$ & $57 \%$ \\
Charcoal & $10 \%$ & $15 \%$ & $72 \%$ \\
\hline
\end{tabular}

\subsection{Composite Preparation}

First, the raw materials (iron ore fines and charcoal or coal) were mixed in a ball mill with a speed of $180 \mathrm{rpm}$ for $1 \mathrm{~h}$ to ensure complete homogeneity. The amount of carbon was calculated to ensure complete removal of the reducible oxygen in the iron ore sample and adjusted at a 3:1 molar ratio. Two types of composites, iron-ore-finescoal and iron-ore-fines-charcoal were prepared and are named hereinafter as composite I and II, respectively.

\subsection{Reduction System and Procedure}

STA 504 (TA Instruments, Lukens Drive, New Castle, DE, USA), a device was equipped with thermogravimetry (TGA) with sensitivity $\pm 1 \mu \mathrm{g}$ and differential thermal analysis (DTA), and connected with quadruple mass spectroscopy (QMS) to measure the gases from the gasification of non-coking coals and monitor the reaction behavior of iron ore/carbon composites. The instrument is represented schematically in Figure 5. In the experiments, the sample (iron-ore-fines-non-coking-coal-composite) is heated in a continuous flow of purified argon gas from room temperature up to $1100^{\circ} \mathrm{C}$ at different heating rates $(5,10$, 15 and $20^{\circ} \mathrm{C} / \mathrm{min}$ ). The mass loss of samples was continually reported as a function of temperature until the completion of the experiment. The Ar gas is introduced with a constant flow rate of $200 \mathrm{~mL} / \mathrm{min}$ to the furnace during heating and cooling of the sample. At the end of the experiment, the furnace was cooling back to room temperature and the reduction product is removed and preserved in a desiccator for the subsequence analyses.

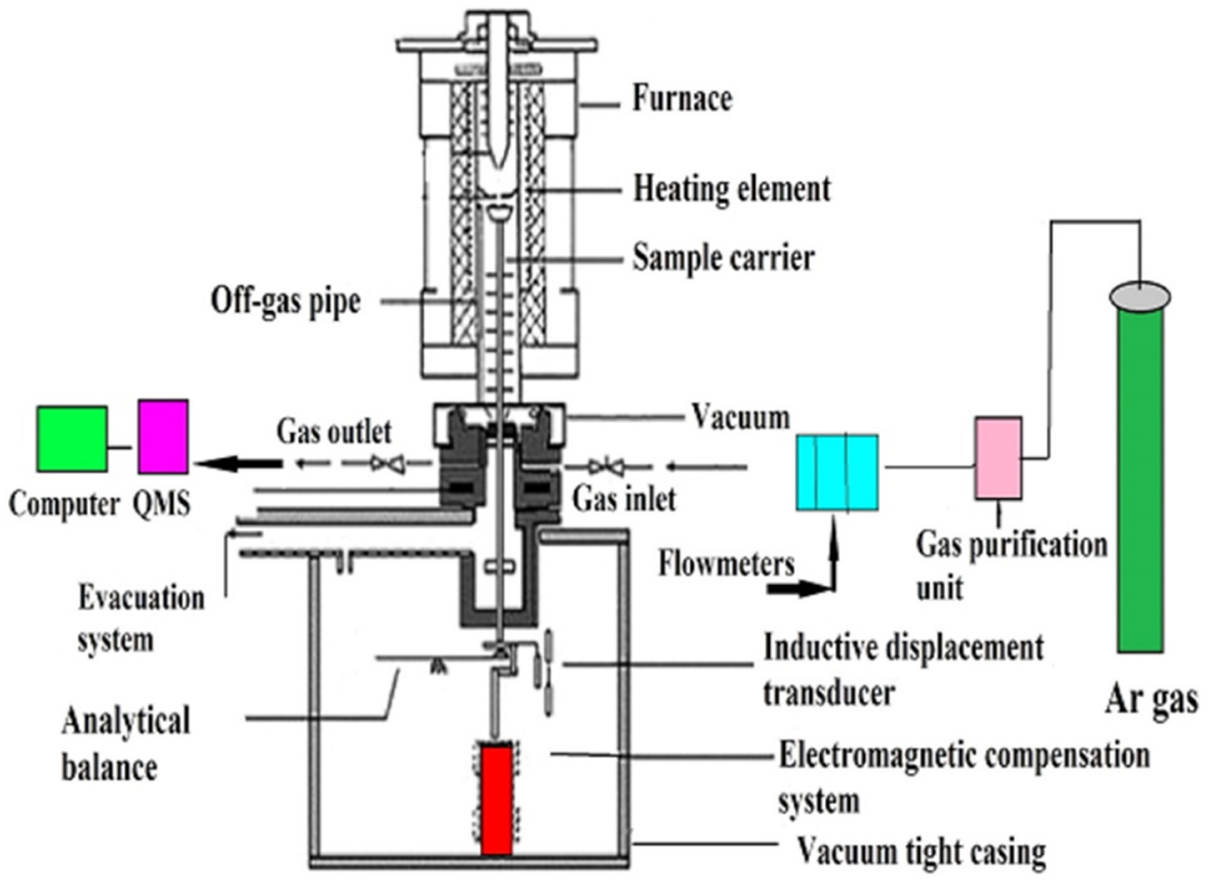

Figure 5. Schematic diagram of TGA/QMS (thermogravimetry/quadruple mass spectroscopy) system. 


\section{Results and Discussion}

\subsection{Reduction of Iron Ore-Coal (Composites I)}

Iron-ore-fines-coal composites were non-isothermally reduced from the room temperature up to $1100{ }^{\circ} \mathrm{C}$ at different heating rates in a continuous flow of Ar gas using the TG technique. Figure 6 gives the influence of different heating rates on the measured weight-loss and on the differential of TG (DTG, \%/min) of composites, respectively. The TG curves show that the heating rate affected the weight loss. A close look at the curves indicates the slopes were slightly changed at the lower temperatures and the changes are more prominent at higher temperature ranges.

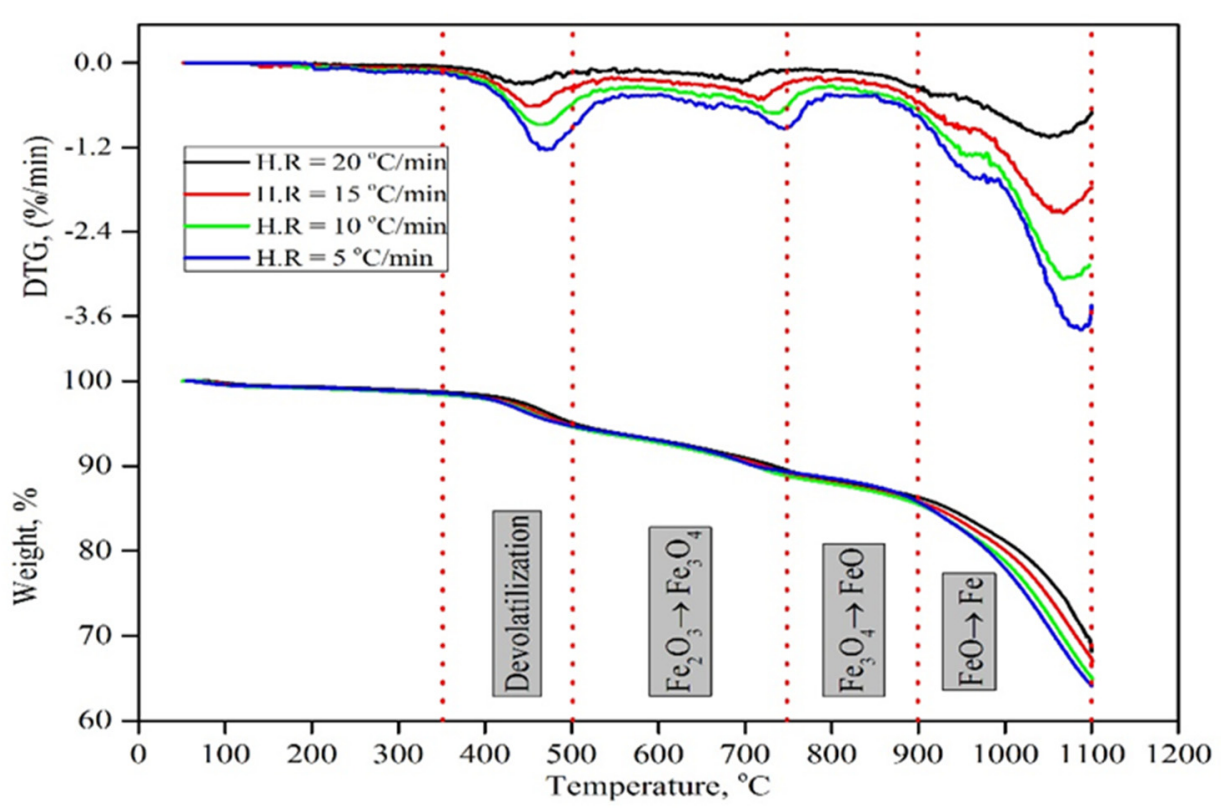

Figure 6. Influence of reduction temperature on the TG and DTG of the iron ore fines-coal composites using different heating rates (H.R).

The TG curves show that the volatiles associated with coal were evolved at temperatures $\left(350-500{ }^{\circ} \mathrm{C}\right)$. By increasing the temperature up to $\left(500-750{ }^{\circ} \mathrm{C}\right), \mathrm{Fe}_{2} \mathrm{O}_{3}$ in composite was stepped wisely reduced to $\mathrm{Fe}_{3} \mathrm{O}_{4}$ with weight loss approximately identical to the theoretical mass loss of $\mathrm{Fe}_{2} \mathrm{O}_{3}$ to $\mathrm{Fe}_{3} \mathrm{O}_{4}$. The weight loss at temperature $\left(750-900{ }^{\circ} \mathrm{C}\right)$ almost equals the theoretical weight loss of the reduction step $\left(\mathrm{Fe}_{3} \mathrm{O}_{4}\right.$ to $\left.\mathrm{FeO}\right)$. Additionally, at a further increase of the temperature $\left(900{ }^{\circ} \mathrm{C}\right)$, wustite $(\mathrm{FeO})$ reduces to metallic iron $(\mathrm{Fe})$.

The DTG curves also present four weight loss steps, which can be clearly identified from the slopes and the peaks of the curves. The first step of weight loss at $350-500{ }^{\circ} \mathrm{C}$ defines the de-volatilization stage of composites. With a further rise in temperature, $\mathrm{Fe}_{2} \mathrm{O}_{3}$ in composite was stepped wisely reduced to $\mathrm{Fe}_{3} \mathrm{O}_{4}$ at $500-750{ }^{\circ} \mathrm{C}$. At a temperature range of $750-900{ }^{\circ} \mathrm{C}, \mathrm{Fe}_{3} \mathrm{O}_{4}$ was reduced to wustite $(\mathrm{FeO})$, and finally, wustite was reduced to metallic iron at a temperature $>900^{\circ} \mathrm{C}$.

\subsection{Reduction of Iron Ore-Charcoal (Composites II)}

Iron-ore-fines-charcoal composites were non-isothermally reduced at the same reduction conditions as composite I. The influence of heating rates on the reduction behavior of composites was intensively studied. Figure 7 shows the effect of heating rates $(5,10,15$ and $20{ }^{\circ} \mathrm{C} / \mathrm{min}$ ) on the measured weight-loss (TG, \%) as well as on the differential of TG (DTG, \%/min) of composites heated up to $1100{ }^{\circ} \mathrm{C}$. 


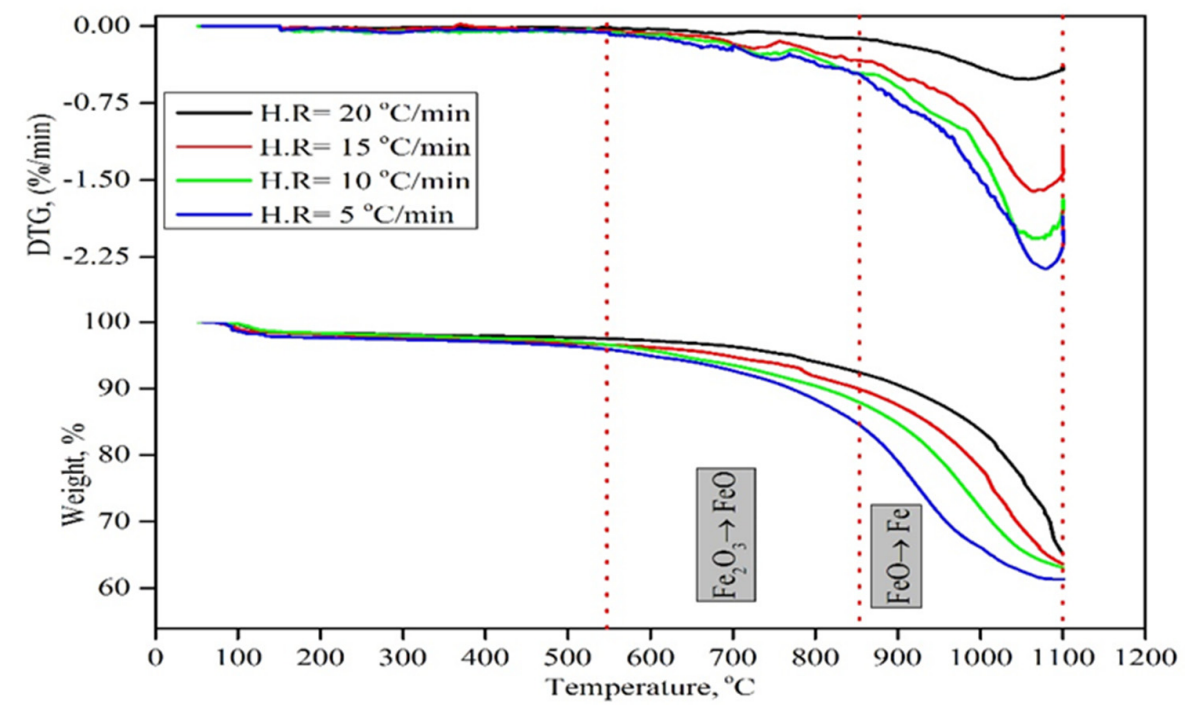

Figure 7. Influence of reduction temperature on the TG and DTG of the iron ore fines-charcoal composites using different heating rates (H.R).

The TG curves show that the rate of heating rate has a substantial impact on weight loss. By increasing the heating rate, the weight loss decreases. A close look at the curves indicates a distinct change of slopes starts at $600{ }^{\circ} \mathrm{C}$ and continues until $1100{ }^{\circ} \mathrm{C}$. At temperature $\left(550-850^{\circ} \mathrm{C}\right)$, the weight loss was almost corresponding to the reduction of $\mathrm{Fe}_{2} \mathrm{O}_{3}$ to $\mathrm{FeO}$. With increasing heating temperature $<850{ }^{\circ} \mathrm{C}$, the weight loss was attributed to the reduction of $\mathrm{FeO}$ to $\mathrm{Fe}$.

The DTG curves show two stages of weight loss, which can be easily determined from the changes in the slope and the peaks of the curves. The first weight loss at $\left(550-850{ }^{\circ} \mathrm{C}\right)$ represents the reduction of $\mathrm{Fe}_{2} \mathrm{O}_{3}$ to wustite $(\mathrm{FeO})$. The second weight loss at higher temperature $\left(850-1100{ }^{\circ} \mathrm{C}\right)$ resulted from $\mathrm{FeO}$, which was further reduced to metallic iron.

\subsection{Reduction Kinetics and Mechanism}

\subsubsection{Reduction of Iron Ore Fines-Coal}

At each heating rate $(\beta)$, different values of conversion degrees $(\alpha)$ were used to compute the $E_{a}$ values according to Equation (5). Figure 8 shows the plots of $\ln \left(\beta / T^{2}\right)$ versus $1 / T$, which corresponds to the conversion degree. Obviously, the relationship between $\ln \left(\beta / T^{2}\right)$ and $1 / T$ was clearly linear, and thus the $E_{a}$ of the reduction reaction of composite I could be determined from the corresponding slopes of drawn lines according to the KAS kinetic approach. The values of $E_{a}$ are given in Table 4.

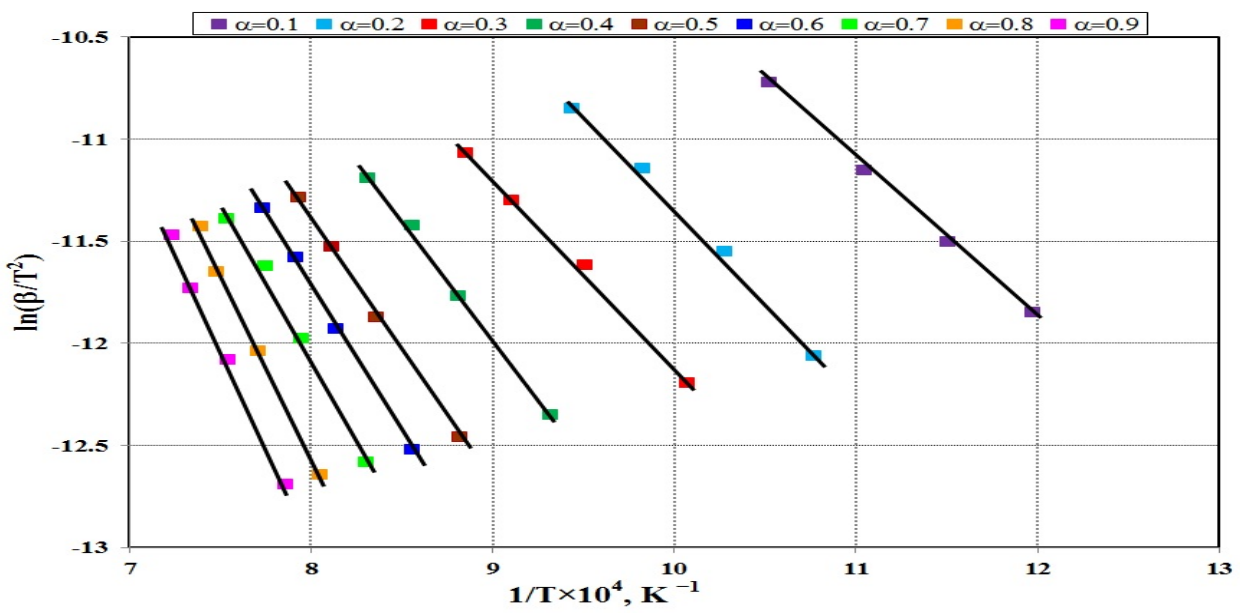

Figure 8. Kissinger plot of $\mathrm{Fe}_{2} \mathrm{O}_{3} /$ coal composites at different conversion degrees $(\alpha)$. 
Table 4. Apparent activation energy values computed at overall reduction reaction.

\begin{tabular}{cccccccccc}
\hline $\begin{array}{c}\text { Conversion } \\
\text { Degree }(\boldsymbol{\alpha})\end{array}$ & $\mathbf{0 . 1}$ & $\mathbf{0 . 2}$ & $\mathbf{0 . 3}$ & $\mathbf{0 . 4}$ & $\mathbf{0 . 5}$ & $\mathbf{0 . 6}$ & $\mathbf{0 . 7}$ & $\mathbf{0 . 8}$ & $\mathbf{0 . 9}$ \\
\hline$E_{a}$ value & 55.02 & 79.12 & 99.47 & 115.07 & 116.72 & 150.73 & 175.22 & 193.803 & 220.12 \\
\hline
\end{tabular}

\section{Model-Fitting (CR) Method}

As aforementioned, in order to predict the most possible reduction, the mechanism CR method was used Equation (6). Numerous models tabulated elsewhere [36] integral form $g(\alpha)$ were verified according to the CR approach. Figure 9 gives a linear relationship between $\ln \left[g(\alpha) / T^{2}\right]$ versus $1 / T$ with a high correlation coefficient $(R)$. Figure 9 shows that the reduction process is characterized by two behaviors. The first one is acquired up to conversion degree $\alpha \leq 0.4$ of the gas diffusion, namely, $\left[g(\alpha)=\alpha^{2}\right]$ offers the best statistical fit with a correlation coefficient $(R=0.99)$. This indicated that gas diffusion is the controlling mechanism of the initial stage. At the final stage up to conversion degree of $0.4<\alpha \leq 0.9$, the nucleation model Avrami-Erofeev (A2), namely, $\left[g(\alpha)=[-\ln (1-\alpha)]^{1 / 2}\right.$ gives a linear pattern with a correlation coefficient $(R)$ greater than 0.99 , suggesting that the reaction is controlled by the Avrami-Erofeev model.

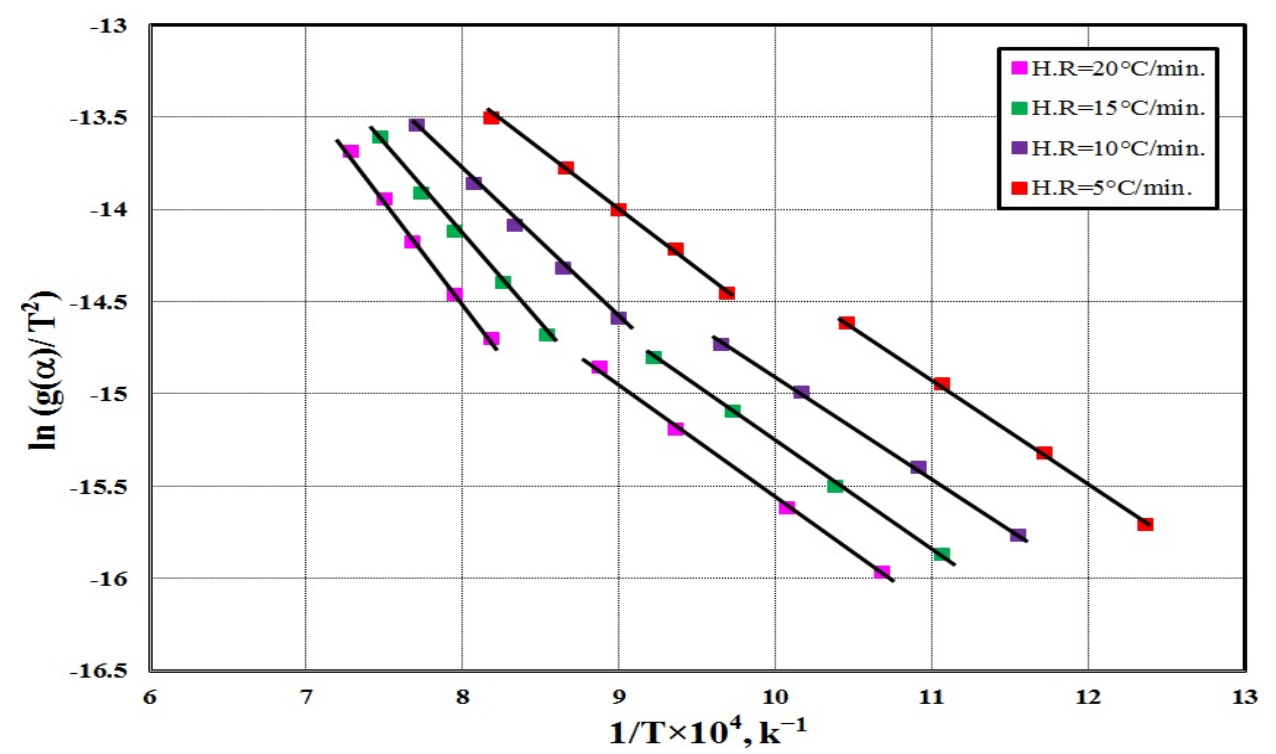

Figure 9. Coats-Redfern plot of composite $I$ at two weight loss stages.

The values of the computed $E_{a}$ at different conversion degrees $(\alpha)$ calculated by the KAS approach are illustrated in Figure 10. It is obvious that the $E_{a}$ changed as the reduction degree was increased, indicating that the chemical reaction varied through the reduction reaction. With a close look at the curve, it can be seen that the reduction of composite I was divided into two stages. During the first stage, the $E_{a}$ stayed relatively constant at a low value $(116.73 \mathrm{~kJ} / \mathrm{mol})$. In stage II, the $E_{a}$ values increase from 116.73 to $220.124 \mathrm{~kJ} / \mathrm{mol}$ as the reduction degree increased.

\subsubsection{Reduction of Iron-Ore-Fines-Charcoal}

At each heating rate $(\beta)$, different values of conversion degrees $(\alpha)$ were used to calculate the $E_{a}$ values according to Equation (5). The plots of $\ln \left(\beta / T^{2}\right)$ against $1 / T$, which corresponds to the conversion degrees, are shown in Figure 11. Clearly, the correlation between $\ln \left(\beta / T^{2}\right)$ and $1 / T$ was linear, and thus the $E_{a}$ for the reduction reaction of composite II is estimated from the corresponding slopes of drawn lines according to the KAS kinetic method. The values of $E_{a}$ are given in Table 5 . 


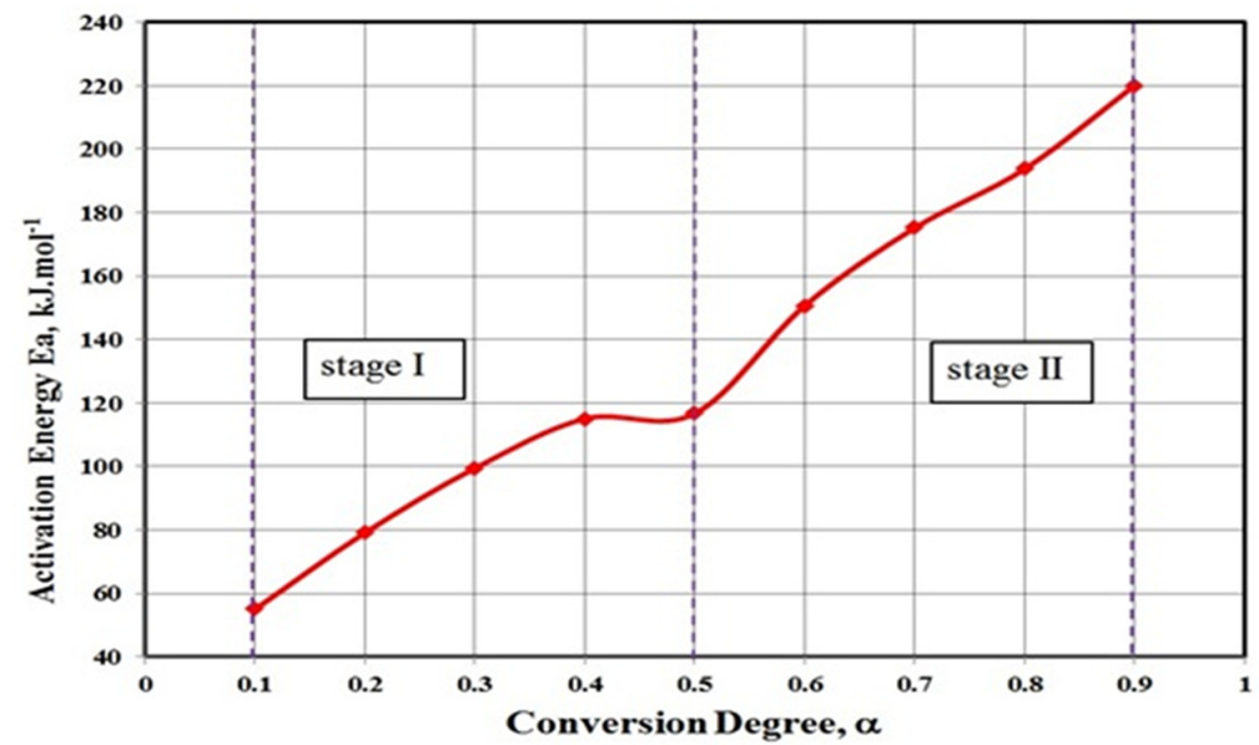

Figure 10. Calculated $E_{a}$ against conversion degree for $\mathrm{Fe}_{2} \mathrm{O}_{3} /$ coal.

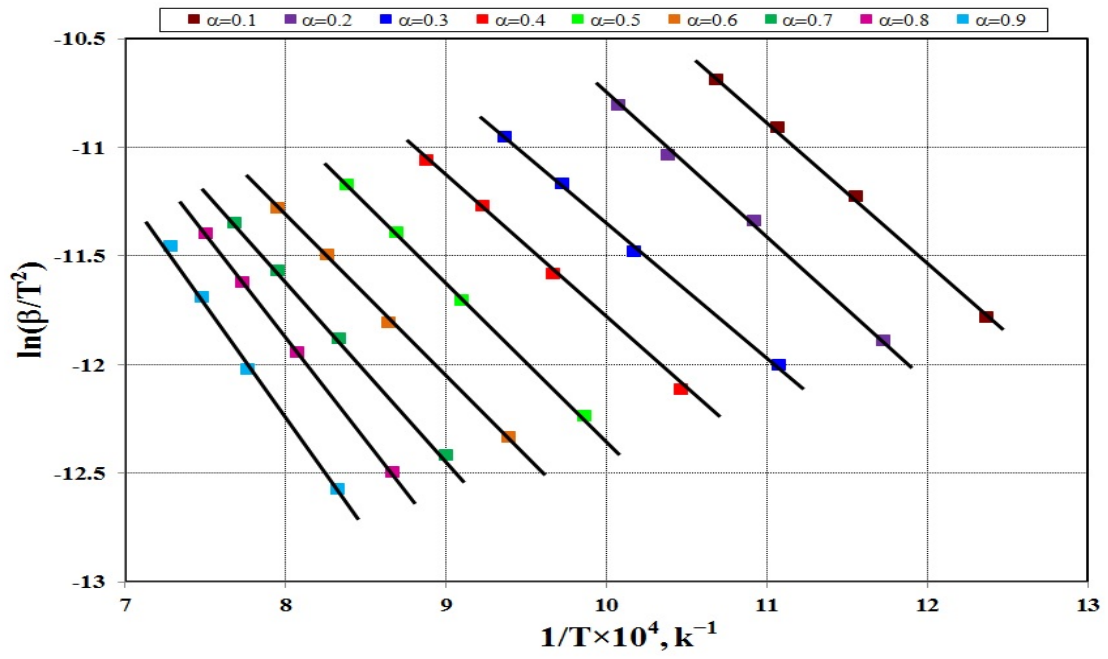

Figure 11. KAS plot of $\mathrm{Fe}_{2} \mathrm{O}_{3} /$ charcoal composites at different weight loss stages.

Table 5. Apparent activation energy values computed at overall reduction reaction.

\begin{tabular}{cccccccccc}
\hline $\begin{array}{c}\text { Conversion } \\
\text { Degree }(\alpha)\end{array}$ & $\mathbf{0 . 1}$ & $\mathbf{0 . 2}$ & $\mathbf{0 . 3}$ & $\mathbf{0 . 4}$ & $\mathbf{0 . 5}$ & $\mathbf{0 . 6}$ & $\mathbf{0 . 7}$ & $\mathbf{0 . 8}$ & $\mathbf{0 . 9}$ \\
\hline$E_{a}$ value & 40.50 & 58.52 & 74.85 & 88.85 & 89.05 & 115.05 & 136.94 & 162.61 & 190.12 \\
\hline
\end{tabular}

It can be reported that the lower values of $E_{a}$ attained for composite II compared to composite I result from the higher surface area, higher fixed carbon, more active sites and higher porosity of charcoal particles. This leads to more chances for the reduction between iron oxide and solid carbon or $\mathrm{CO}$ gas (direct and indirect reduction reactions).

\section{Model-Fitting (CR) Method}

Figure 12 shows a linear plot of $\ln \left[g(\alpha) / T^{2}\right]$ against $1 / T$ with a high correlation coefficient $(R)$. Figure 12 illustrates that the reduction process is characterized by two behaviors. The first one is acquired up to conversion degree $\alpha \leq 0.4$ of the gas diffusion, namely, $\left[g(\alpha)=\alpha^{2}\right]$ gives the best statistical fit with a correlation coefficient $(R)$ higher than 0.99 . This indicated that gas diffusion is the controlling mechanism of the initial 
stage. At the final stage up to the conversion degree of $0.4<\alpha \leq 0.9$, the nucleation model of Avrami-Erofeev (A2), namely $\left[g(\alpha)=[-\ln (1-\alpha)]^{1 / 2}\right.$, gives the best statistical fit with a correlation coefficient $(R=0.99)$. This revealed that the Avrami-Erofeev model is the controlling mechanism of this stage.

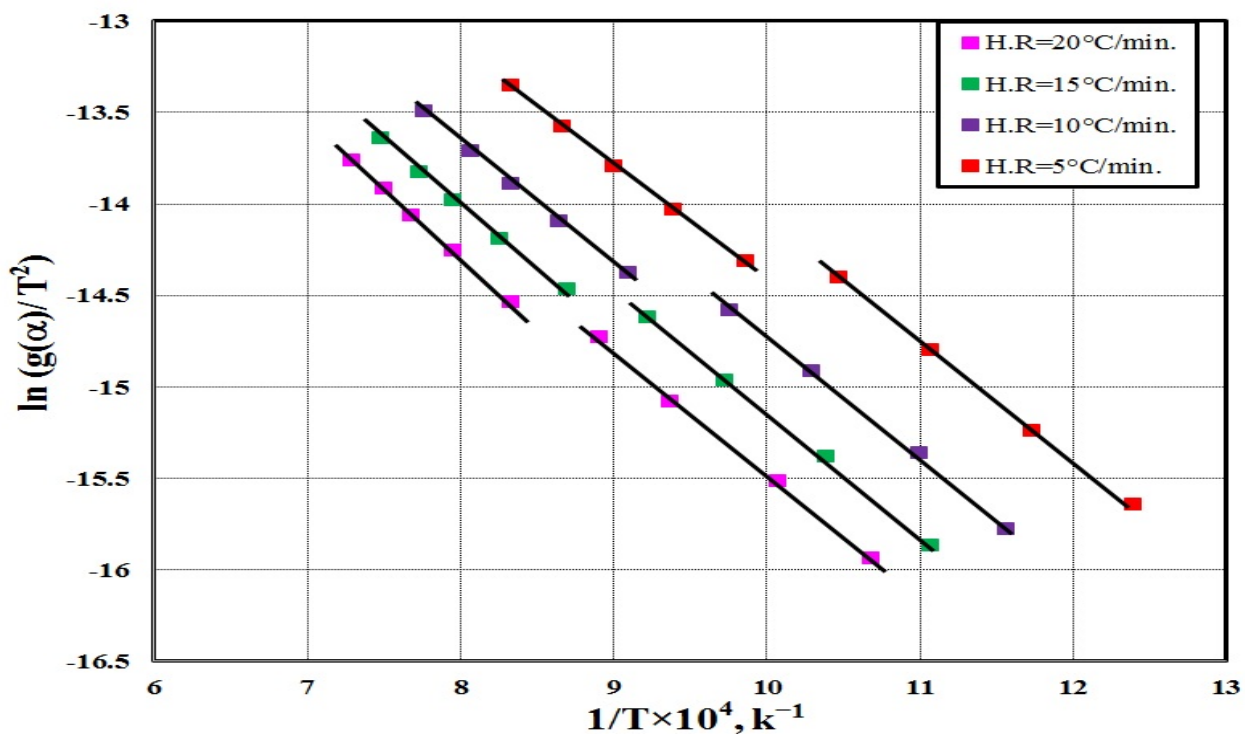

Figure 12. Coats-Redfern plot of $\mathrm{Fe}_{2} \mathrm{O}_{3}$ / charcoal composite at two weight loss stages.

The values of computed $E_{a}$ at different conversion degrees $(\alpha)$ are given in Figure 13. The $E_{a}$ changed as the reduction degree increased, meaning that the chemical reaction changed during the reduction process. A closer analysis of the curve shows that the reduction of composite II was divided into two stages. In Stage I, the $E_{a}$ stayed relatively constant at a low value $\left(88.16 \mathrm{~kJ} \mathrm{~mol}^{-1}\right)$. In stage II, the $E_{a}$ increased rapidly from 88.16 to $190.22 \mathrm{~kJ} / \mathrm{mol}$ with an increasing degree of reduction.

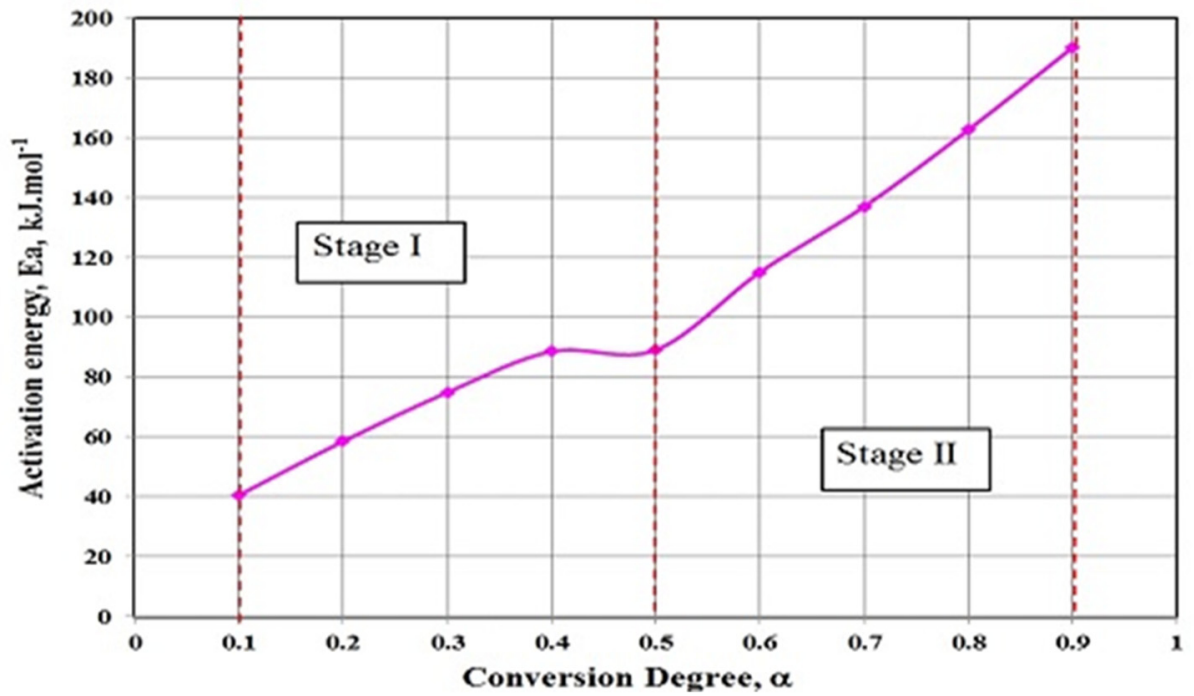

Figure 13. Calculated $E_{a}$ against conversion degree for $\mathrm{Fe}_{2} \mathrm{O}_{3}$ / charcoal composite.

The influence of heating rate on the internal structure of reduced composites I and II in Figures 14 and 15, respectively. At a high heating rate $\left(20^{\circ} \mathrm{C} / \mathrm{min}\right)$ (Figures $14 \mathrm{a}$ and 15a), the sample contains the formation of metallic iron whiskers, and their amount relatively decreases with the decreasing heating rate. At a low heating rate $\left(5^{\circ} \mathrm{C} / \mathrm{min}\right)$ (Figures $14 \mathrm{~b}$ and 15b), no iron whiskers were observed, and the internal structure of metal- 
lic iron grains becomes relatively denser due to the adhesion and the connection between the metallic iron grains.
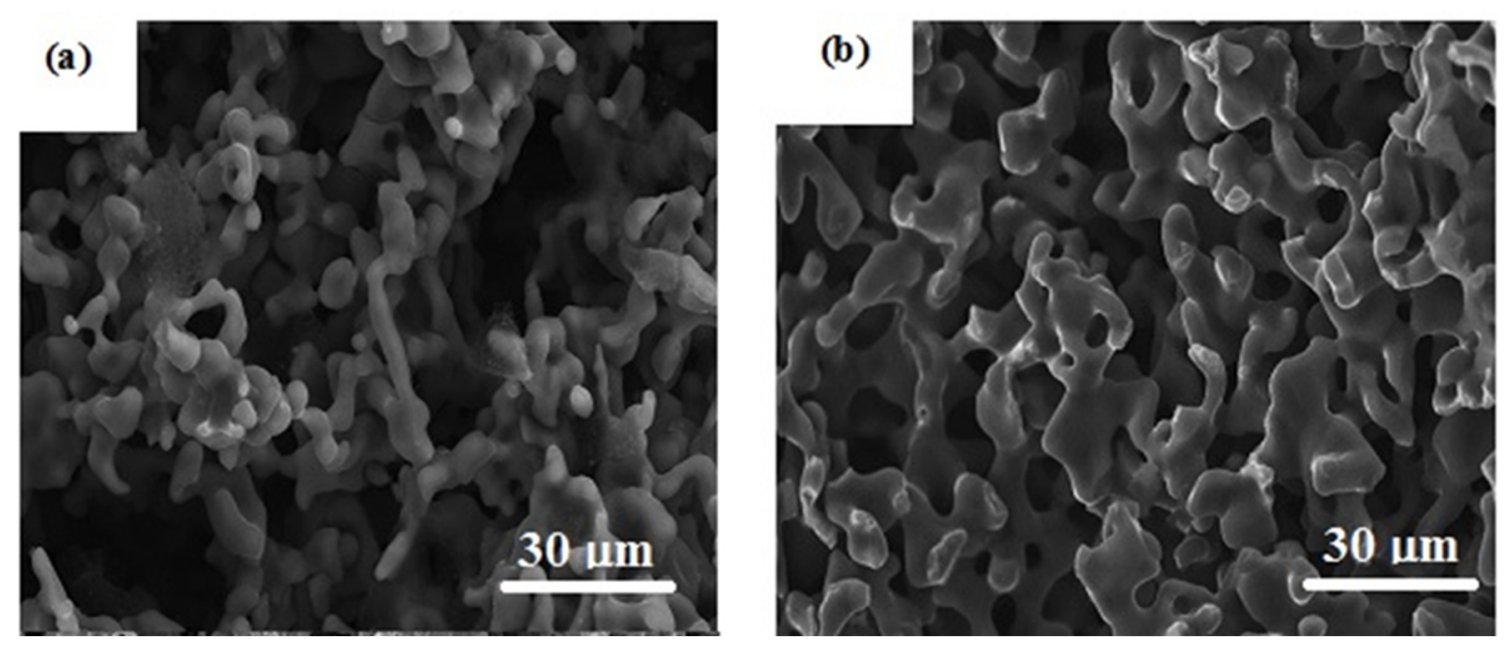

Figure 14. SEM photomicrographs of $\mathrm{Fe}_{2} \mathrm{O}_{3} /$ charcoal composites reduced at different heating rates: (a) $20^{\circ} \mathrm{C} / \mathrm{min}$ and (b) $5{ }^{\circ} \mathrm{C} / \mathrm{min}$.
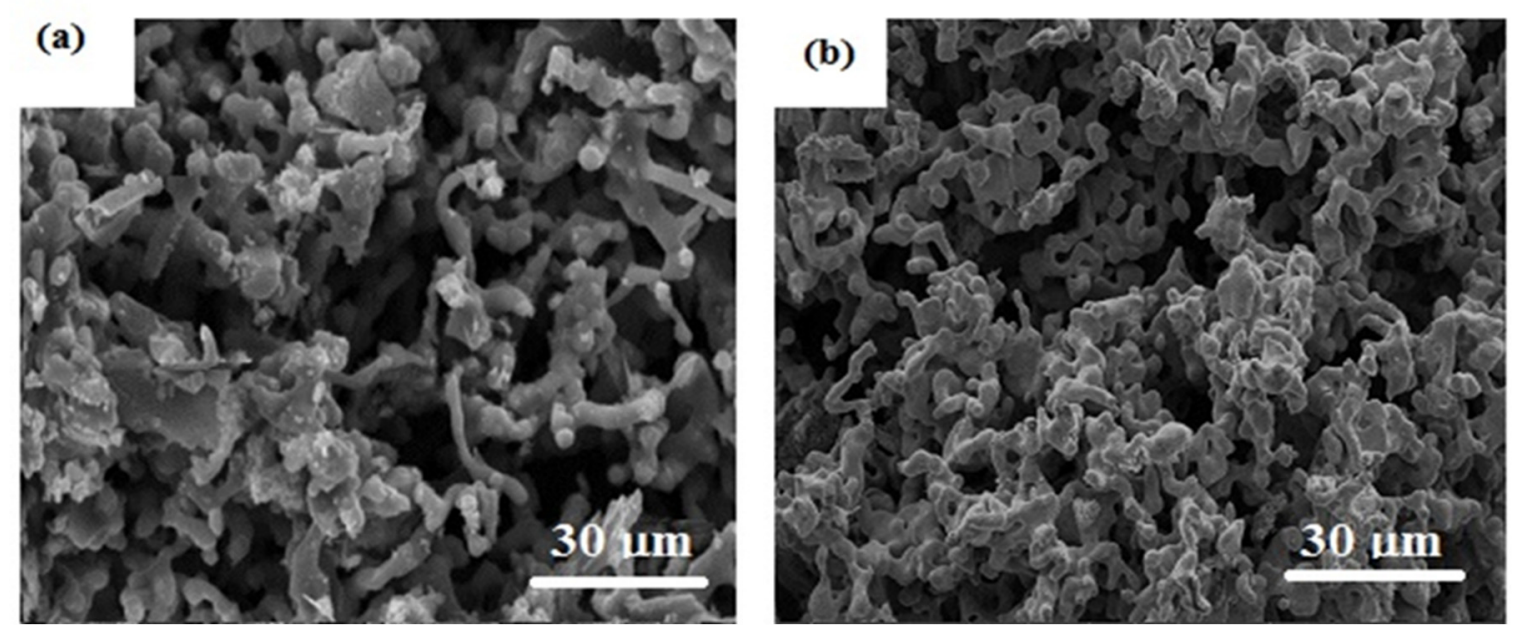

Figure 15. SEM Photo micrographs of $\mathrm{Fe}_{2} \mathrm{O}_{3} /$ coal composites reduced at different heating rates: (a) $20^{\circ} \mathrm{C} / \mathrm{min}$ and (b) $5^{\circ} \mathrm{C} / \mathrm{min}$.

The microstructure of iron-ore-fines-charcoal composites reduced at different heating rates $\left(20,15,10\right.$ and $5{ }^{\circ} \mathrm{C} / \mathrm{min}$.) up to $1100{ }^{\circ} \mathrm{C}$ are given in Figure $16 \mathrm{a}-\mathrm{d}$, respectively. In Figure 16a, it can be seen that the structure includes small bright patches of bright metallic iron grains scatters together with the wustite all over the sample. For the sample, it did not reach a $100 \%$ reduction. Figure $16 \mathrm{~b}$ indicates that almost all the iron oxide grains were reduced to metallic iron. The morphological structure of reduced composites displayed a relatively large size of metallic iron grains connected together to form a dense matrix. The microstructure of reduced composite, as given in Figure 16c, showed that a porous structure from the large connected iron grains was formed. This is attributed to the sintering of the grains and caused the collapse of microspores inside the iron grains as well as the impinging of the iron grains to each other, forming larger grains with rounded edges. This is due to the grains sintering, which caused the microspores within the iron grains to collapse, as well as the iron grains impinging on each other, resulting in bigger grains with rounded edges. As given in Figure 16d, metallic iron grains are a remarkably bigger size as a result of reduction at a low heating rate $\left(5^{\circ} \mathrm{C} / \mathrm{min}\right)$. Most of the iron grains 
attain in the cracks and crevices, which is due to the effect of the $\mathrm{CO}_{2}$ produced as a result of the reduction of iron oxide surrounded by dense iron phase. $\mathrm{CO}_{2}$ was accumulated in microspores and built up pressure, which finally caused cracks in the iron phase to allow for pressure release.
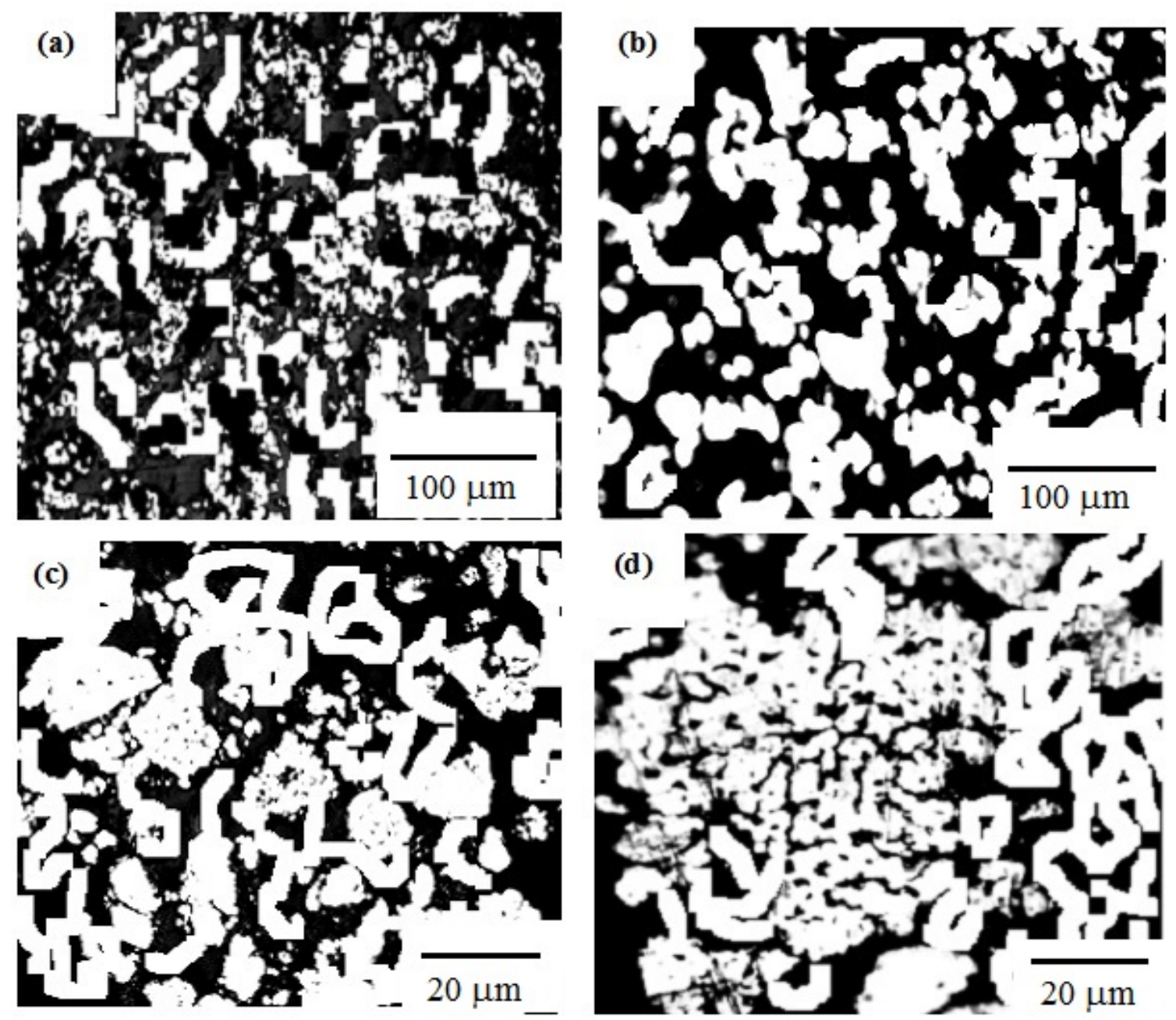

Figure 16. RLM photomicrograph of $\mathrm{Fe}_{2} \mathrm{O}_{3}$-charcoal composite reduced up to $1100{ }^{\circ} \mathrm{C}$ at different heating rates: (a) $20{ }^{\circ} \mathrm{C} / \mathrm{min},(\mathbf{b}) 10^{\circ} \mathrm{C} / \mathrm{min}$, (c) $15^{\circ} \mathrm{C} / \mathrm{min}$ and (d) $5{ }^{\circ} \mathrm{C} / \mathrm{min}$.

The microstructure of iron-ore-fines-coal composites reduced at different heating rates is given in Figure 17a-d, respectively. In Figure 17a, it can be shown that the structure includes some bright patches of metallic iron together with wustite all over the sample. Figure $17 \mathrm{~b}$ shows that almost all the iron oxide grains were reduced to metallic iron. The reduced iron phase showed small bright white grains of metallic iron scatter all over the sample, forming a dense matrix. Figure $17 \mathrm{c}$ shows a relatively porous structure due to the connecting of metallic iron grains. The microstructure of reduced composite in Figure $17 \mathrm{~d}$ shows relatively large iron grains connecting to each other forming dense structures. Macrospores are the main type of pores among the grains observed in the sample, and these were attributed to the sintering of iron grains at $1100^{\circ} \mathrm{C}$. At such a high temperature, micropores inside the solid grains were gradually collapsed and eventually removed, leaving only manropes prevailing throughout the sample.

Figure 18 shows the XRD patterns of the partial reduction of iron ore/coal composites. The different phases formed in the reduction of the composite were identified by XRD. It is clear that the main phases were hematite, magnetite, wustite and metallic iron. The 
reduction of iron ore fines was found to proceed in a stepwise manner from $\mathrm{Fe}_{2} \mathrm{O}_{3}$ to metallic iron $\left(\mathrm{Fe}_{2} \mathrm{O}_{3} \rightarrow \mathrm{Fe}_{3} \mathrm{O}_{4} \rightarrow \mathrm{FeO} \rightarrow \mathrm{Fe}\right)$.
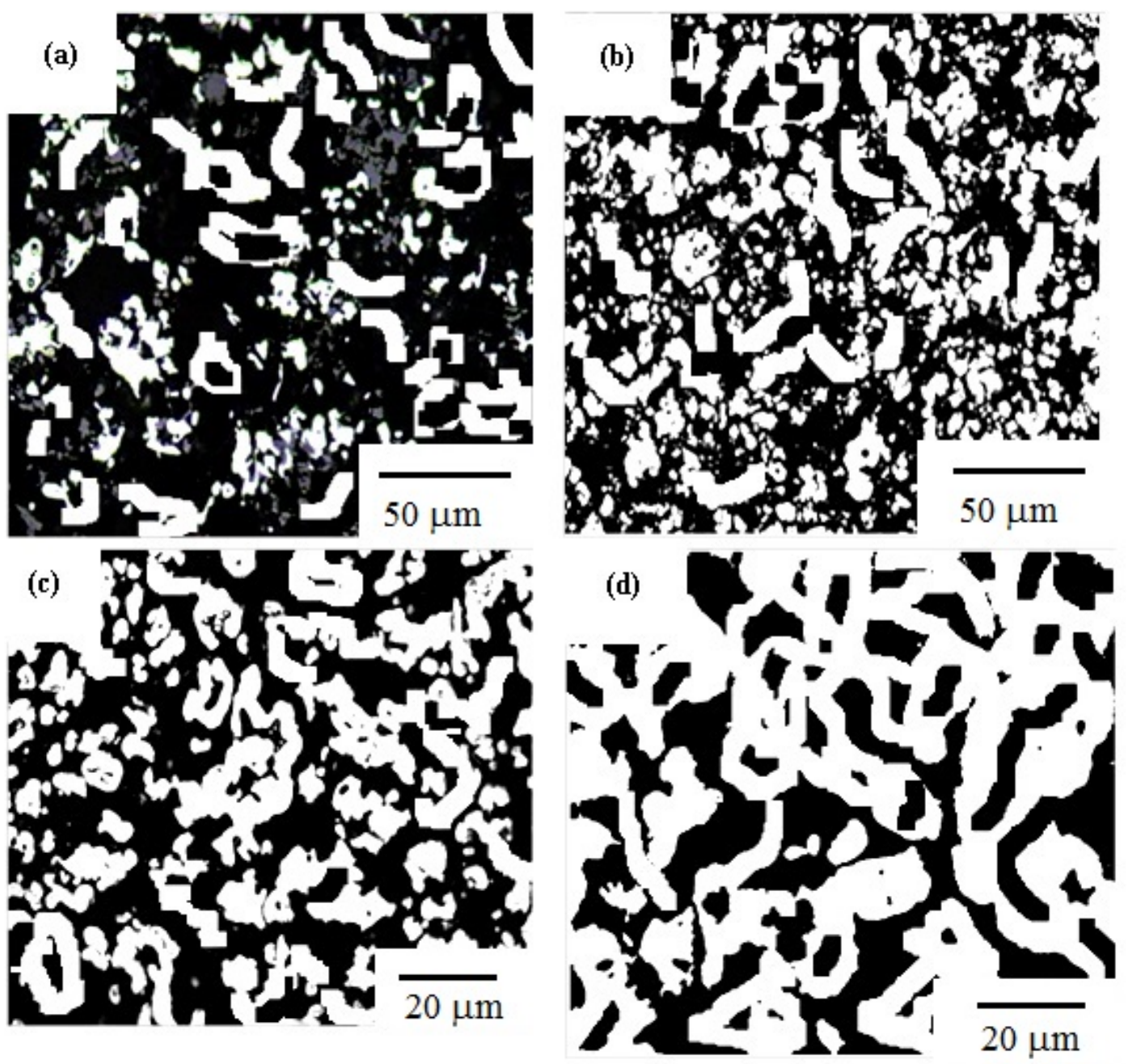

Figure 17. RLM photomicrograph of iron ore-coal composite reduced up to $1100{ }^{\circ} \mathrm{C}$ at different heating rates: (a) $20^{\circ} \mathrm{C} / \mathrm{min}$, (b) $10{ }^{\circ} \mathrm{C} / \mathrm{min}$, (c) $15^{\circ} \mathrm{C} / \mathrm{min}$ and (d) $5^{\circ} \mathrm{C} / \mathrm{min}$.

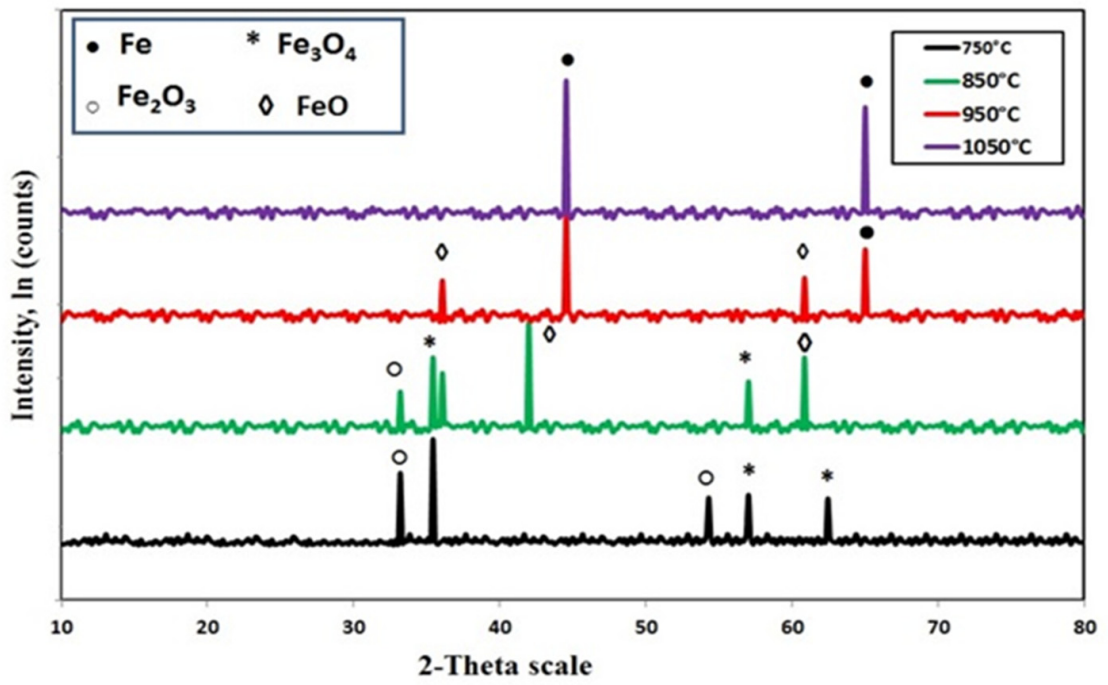

Figure 18. XRD patterns of the samples partially reduced by coal. 
Figure 19 presents the XRD patterns of partial reduction of iron-ore-fines-charcoal composite. It is clear that the main phases of this sample were hematite, wustite and metallic iron. The reduction of $\mathrm{Fe}_{2} \mathrm{O}_{3}$ was found to proceed as follows $\left(\mathrm{Fe}_{2} \mathrm{O}_{3} \rightarrow \mathrm{FeO} \rightarrow \mathrm{Fe}\right)$.

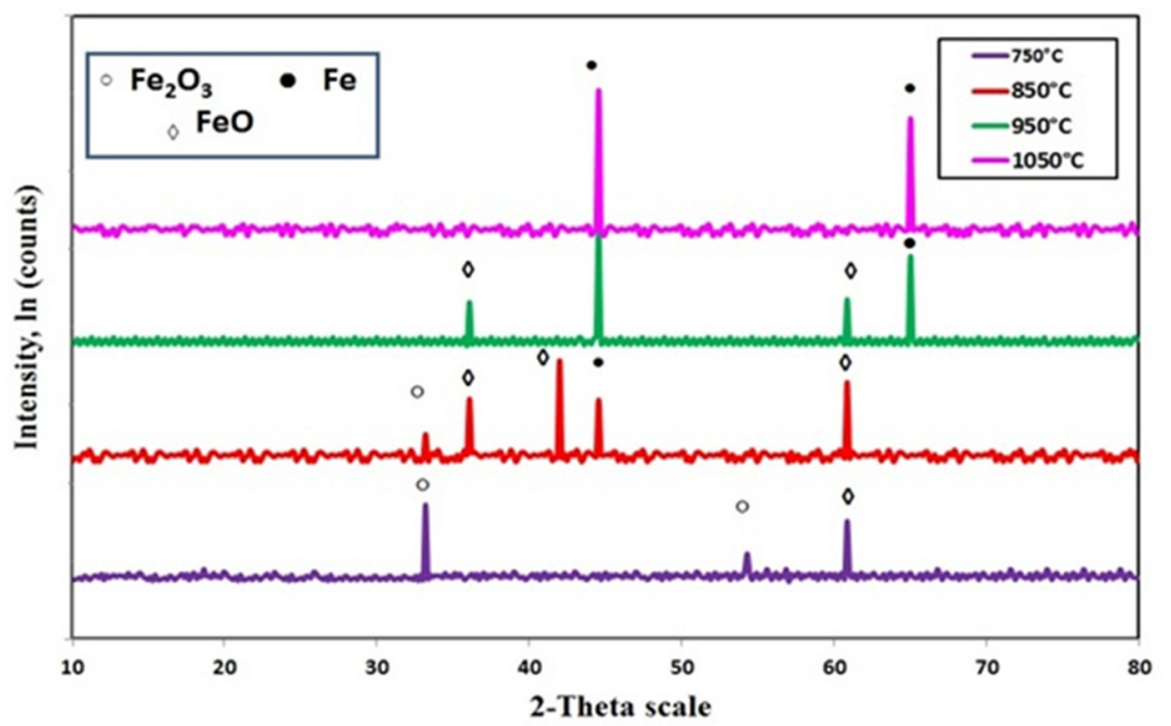

Figure 19. XRD patterns of the samples partially reduced by charcoal.

\section{Conclusions}

Understanding and investigating the kinetic parameters under non-isothermal conditions are supportive in the DR process. DR process is considered as a promising way to decrease $\mathrm{CO}_{2}$ emissions and use of coke in the iron and steel industry by utilization of non-coking coal. This study aims to develop new raw materials and methods for the steelmaking industry by studying the kinetics of the reaction of these materials and their impact on the reduction process.

This work investigated the reduction of iron ore fines by charcoal and coal under non-isothermal conditions. During the experiments, the total mass loss was continuously monitored using the TG technique. The reduction mechanism and kinetic parameters were analyzed. The main conclusions can be drawn:

- The heating rate had a considerable impact on the rate of reduction and reduction conversion. At the same heating rate, the reduction degree is higher with charcoal than with coal.

- The computed $E_{a}$ values for the reduction of iron-ore-fines-charcoal composites range from 40.50 to $190.12 \mathrm{~kJ} / \mathrm{mol}$ while the $E_{a}$ values for the reduction of iron ore fines/coal range from 55.02 to $220.12 \mathrm{~kJ} / \mathrm{mol}$.

- $\quad$ By the CR approach, the reduction reaction was controlled by the gas diffusion model at the initial stage, while at the final stages, the nucleation (Avrami-Erofeev) model was the controlling mechanism.

- The reduction process of iron-ore-fines-charcoal was found to proceed step wisely as follows: $\mathrm{Fe}_{2} \mathrm{O}_{3} \rightarrow \mathrm{FeO} \rightarrow$ Fe.

- The reduction process of iron-ore-fines-coal was found to proceed step wisely as follows: $\mathrm{Fe}_{2} \mathrm{O}_{3} \rightarrow \mathrm{Fe}_{3} \mathrm{O}_{4} \rightarrow \mathrm{FeO} \rightarrow$ Fe.

Author Contributions: Conceptualization, A.H. and Y.Y.; methodology, A.-H.A.E.-G. and M.H.E.-S.; software, Y.L., H.W. and Y.C.; validation, A.H., A.-H.A.E.-G., M.H.E.-S. and Y.Y.; formal analysis, A.H., M.H.E.-S. and M.O.; investigation, A.H., M.H.E.-S., M.O., A.-H.A.E.-G. and Y.Y.; resources, H.W., Y.L. and Y.C.; data curation, A.H. and M.H.E.-S.; writing-original draft preparation, A.H.; writing-review and editing, Y.Y., M.O., A.H., A.-H.A.E.-G. and M.H.E.-S.; supervision, Y.Y. and M.O.; project administration, Y.Y.; funding acquisition, M.O. and Y.Y. All authors have read and agreed to the published version of the manuscript. 
Funding: This research was funded by the Program for Professor of Special Appointment (Eastern Scholar) at the Shanghai Institutions of Higher Learning (No.TP2015039), the National Natural Science Foundation of China (No.51974182), National 111 project, Grant/Award No. 17002 and CSC support for a Ph.D. from the Belt and Road Countries.

Data Availability Statement: Data presented in this article is available at request from the corresponding author.

Acknowledgments: We gratefully acknowledge financial support from The Program for Professor of Special Appointment (Eastern Scholar) at the Shanghai Institutions of Higher Learning.

Conflicts of Interest: The authors declare no conflict of interest.

\section{References}

1. Pardo, N.; Moya, J.A. Prospective scenarios on energy efficiency and $\mathrm{CO}_{2}$ emissions in the European Iron \& Steel industry. Energy 2013, 54, 113-128. [CrossRef]

2. Mousa, E.; Wang, C.; Riesbeck, J.; Larsson, M. Biomass applications in iron and steel industry: An overview of challenges and opportunities. Renew. Sustain. Energy Rev. 2016, 65, 1247-1266. [CrossRef]

3. Ahmed, H. New trends in the application of carbon-bearing materials in blast furnace iron-making. Minerals $2018,8,561$. [CrossRef]

4. Gielen, D. Energy Technology Perspectives 2008: Scenarios and Strategies for CO2 Emissions Reduction. Int. J. Gas Turbine Propuls. Power Syst. 2010, 3, 1-9. [CrossRef]

5. Wang, X.; Lin, B. How to reduce $\mathrm{CO}_{2}$ emissions in China's iron and steel industry. Renew. Sustain. Energy Rev. 2016, 57, 1496-1505. [CrossRef]

6. Barella, S.; Bondi, E.; Di Cecca, C.; Ciuffini, A.F.; Gruttadauria, A.; Mapelli, C.; Mombelli, D. New perspectivein steelmaking activity to increase competitiveness and reduce environmental impact. La Metall. Ital. 2014, 16, 31-40.

7. Sarkar, S.; Mazumder, D. Solid waste management in steel industry-challenges and opportunities.Eng.Technol. Int. J. Soc. Behav. Educ. Econ. Bus. Ind. Eng. 2015, 9, 978-981.

8. Rieger, J.; Schenk, J.; Rieger, J.; Schenk, J. Residual processing in the European steel industry: A technological overview. J. Sustain. Met. 2019, 5, 295-309. [CrossRef]

9. Branca, T.A.; Colla, V.; Algermissen, D.; Granbom, H.; Martini, U.; Morillon, A.; Pietruck, R.; Rosendahl, S. Reuse and recycling of by-products in the steel sector: Recent achievements paving the way to circular economy and industrial symbiosis in Europe. Metals 2020, 10, 345. [CrossRef]

10. Kaushik, P.; Fruehan, R.J.; Kaushik, P.; Fruehan, R.J. Behavior of direct reduced iron and hot briquetted iron in the upper blast furnace shaft: Part I. Fundamentals of kinetics and mechanism of oxidation. Met. Mater. Trans. A 2006, 37, 715-725. [CrossRef]

11. Sah, R.; Dutta, S.K. Kinetic studies of iron ore-coal composite pellet reduction by TG-DTA. Trans. Indian Inst. Met. 2011, 64, 583-591. [CrossRef]

12. Liu, G.-S.; Strezov, V.; Lucas, J.; Wibberley, L.J. Thermal investigations of direct iron ore reduction with coal. Thermochim. Acta 2004, 410, 133-140. [CrossRef]

13. Chatterjee, A. Beyond the Blast Furnace; CRC Press: Boca Raton, FL, USA, 1993.

14. Ding, Y.L.; Warner, N.A. Reduction of carbon-chromite composite pellets with silica flux. Ironmak. Steelmak. 1997, $24,283-287$.

15. van Duong, H.; Johnston, R.F. Kinetics of solid state silica fluxed reduction of chromite with coal. Ironmak. Steelmak. 2000, 27, 202-206. [CrossRef]

16. Srivastava, U.; Kawatra, S.K. Strategies for processing low-grade iron ore minerals. Miner. Process. Extr. Metall. Rev. 2009, 30, 361-371. [CrossRef]

17. Sun, Y.-S.; Han, Y.-X.; Gao, P.; Wang, Z.-H.; Ren, D.-Z. Recovery of iron from high phosphorus oolitic iron ore using coal-based reduction followed by magnetic separation. Int. J. Miner. Metall. Mater. 2013, 20, 411-419. [CrossRef]

18. Yu, W.; Sun, T.; Kou, J.; Wei, Y.; Xu, C.; Liu, Z. The function of $\mathrm{Ca}(\mathrm{OH}) 2$ and Na2CO3 as additive on the reduction of high-phosphorus oolitic hematite-coal mixed pellets. ISIJ Int. 2013, 53, 427-433. [CrossRef]

19. Yu, W.; Sun, T.; Liu, Z.; Kou, J.; Xu, C. Effects of particle sizes of iron ore and coal on the strength and reduction of high phosphorus oolitic hematite-coal composite briquettes. ISIJ Int. 2014, 54, 56-62. [CrossRef]

20. Li, S.F.; Sun, Y.S.; Han, Y.X.; Shi, G.Q.; Gao, P. Fundamental research in utilization of an oolitic hematite by deep reduction. Adv. Mater. Res. 2010, 158, 106-112. [CrossRef]

21. Li, K.-Q.; Ni, W.; Zhu, M.; Zheng, M.-J.; Li, Y. Iron extraction from oolitic iron ore by a deep reduction process. J. Iron Steel Res. Int. 2011, 18, 9-13. [CrossRef]

22. El-Sadek, M.H.; Ahmed, H.M.; El-Barawy, K.; Morsi, M.B.; El-Didamony, H.; Björkman, B. Non-isothermal carbothermic reduction kinetics of mechanically activated ilmenite containing self-reducing mixtures. J. Therm. Anal. Calorim. 2017, 131, $2457-2465$. [CrossRef]

23. Hammam, A.; Li, Y.; Nie, H.; Zan, L.; Ding, W.; Ge, Y.; Li, M.; Omran, M.; Yu, Y. Isothermal and non-isothermal reduction behaviors of iron ore compacts in pure hydrogen atmosphere and kinetic analysis. Min. Metall. Explor. 2021, 38, 81-93. [CrossRef] 
24. Huang, B.-H.; Lu, W.-K. Kinetics and mechanisms of reactions in iron ore/coal composites. ISIJ Int. 1993, 33, 1055-1061. [CrossRef]

25. Dutta, S.K.; Ghosh, A.; Dutta, S.K.; Ghosh, A. Study of nonisothermal reduction of iron ore-coal/char composite pellet. Metall. Mater. Trans. A 1994, 25, 15-26. [CrossRef]

26. Sun, S.; Lu, W.-K. A theoretical investigation of kinetics and mechanisms of iron ore reduction in an ore/coal composite. ISIJ Int. 1999, 39, 123-129. [CrossRef]

27. Sun, Y.S.; Han, Y.X.; Gao, P.; Li, G.F. Investigation of kinetics of coal based reduction of oolitic iron ore. Ironmak. Steelmak. 2014, 41, 763-768. [CrossRef]

28. Sun, S.; Lu, W.-K. Building of a mathematical model for the reduction of iron ore in ore/coal composites. ISIJ Int. 1999, 39, 130-138. [CrossRef]

29. Sbirrazzuoli, N.; Vincent, L.; Mija, A.; Guigo, N. Integral, differential and advanced isoconversional methods: Complex mechanisms and isothermal predicted conversion-time curves. Chemom. Intell. Lab. Syst. 2009, 96, 219-226. [CrossRef]

30. Šimon, P. Isoconversional methods. J. Therm. Anal. Calorim. 2004, 76, 123-132. [CrossRef]

31. Khawam, A.; Flanagan, D.R. Role of isoconversional methods in varying activation energies of solid-state kinetics: I. Isothermal kinetic studies. Thermochim. Acta 2005, 429, 93-102. [CrossRef]

32. Khawam, A.; Flanagan, D.R. Role of isoconversional methods in varying activation energies of solid-state kinetics: II. Nonisothermal kinetic studies. Thermochim. Acta 2005, 436, 101-112. [CrossRef]

33. Vyazovkin, S. Computational aspects of kinetic analysis.: Part C. The ICTAC Kinetics Project-The light at the end of the tunnel? Thermochim. Acta 2000, 355, 155-163. [CrossRef]

34. Burnham, A.K. Computational aspects of kinetic analysis.: Part D: The ICTAC kinetics project-Multi-thermal-history modelfitting methods and their relation to isoconversional methods. Thermochim. Acta 2000, 355, 165-170. [CrossRef]

35. Coats, A.W.; Redfern, J.P. Kinetic parameters from thermogravimetric data. Nat. Cell Biol. 1964, 201, 68-69. [CrossRef]

36. Sun, Y.; Han, Y.; Wei, X.; Gao, P. Non-isothermal reduction kinetics of oolitic iron ore in ore/coal mixture. J. Therm. Anal. Calorim. 2016, 123, 703-715. [CrossRef] 